\title{
Transfer Teknologi Pengolahan Daging Bebek
}

\author{
Siska Cicilia ${ }^{1}$, Rini Nofrida ${ }^{2}$ \\ Program Studi Ilmu dan Teknologi Pangan, Fakultas Teknologi Pangan dan Agroindustri ${ }^{1,2}$ \\ e-mail: siskacicilia@unram.ac.id ${ }^{1}$, rininofrida@unram.ac.id ${ }^{2}$
}

\begin{abstract}
Abstrak
Bebek merupakan salah satu jenis unggas yang banyak dipelihara dan dibudidayakan untuk dimanfaatkan oleh manusia. Pemanfaatan daging bebek sudah banyak dilakukan menjadi beberapa produk olahan seperti lalapan dan geprek. Kedua produk tersebut sedang menjadi trend kuliner di masyarakat. Salah satu daerah yang masyarakatnya banyak menjadi peternak bebek adalah Desa Pengadang Praya Lombok Tengah. Kendala yang dihadapi adalah sebagian dari peternak belum memiliki pengetahuan dan keterampilan dalam mengolah daging bebek sehingga mereka menjual daging bebek ke pedagang lalapan yang ada di Lombok Tengah hingga Mataram. Tujuan kegiatan pelatihan ini dapat memberi tambahan pengetahuan dan keterampilan dalam mengolah daging bebek menjadi produk lainnya. Kegiatan ini melibatkan peternak bebek dan ibu-ibu rumah tangga di desa tersebut dengan memberikan transfer teknologi jenis olahan daging bebek dilanjutkan dengan membuat olahan daging bebek tersebut. Pada akhir kegiatan dilakukan evaluasi dan menunjukkan para peserta mendapat peningkatan pengetahuan tentang jenis-jenis olahan daging bebek dan cara pengolahan yang tepat.
\end{abstract}

Kata kunci: geprek, olahan bebek, teknologi pengolahan

\section{Abstract}

Ducks are one type of poultry that is widely maintained and cultivated for human use. Utilization of duck meat has been done into several processed products such as lalapan and geprek. Both products are becoming a culinary trend in the community. One area where many people become duck farmers is Pengadang Praya Village, Central Lombok. The obstacle currently faced is that some of the farmers do not have the knowledge and skills in processing duck meat. Therefore they sell duck meat to lalapan traders in Central Lombok to Mataram. The purpose of this training was to provide additional knowledge and skills in processing duck meat to other products. This activity involved duck breeders and homemakers in the village by providing technology transfer of the processed duck meat types followed by practising how to make the processed duck meat. At the end of the activity, an evaluation was conducted that showed the participants increment in knowledge on the types of processed duck meat and the proper processing methods.

Keywords: geprek, ducks product, food processing

\section{PENDAHULUAN}

Konsumsi daging di Indonesia umumnya berasal dari daging sapi. Pada saat ini peningkatan permintaan daging belum dapat diimbangi oleh laju peningkatan produksi, sehingga masih diperlukan impor daging. Impor daging ini terutama diperlukan untuk memenuhi permintaan konsumen, hotel atau restoran yang membutuhkan daging bermutu baik. Oleh karena itu perlu dicari penghasil daging selain ternak ruminansia besar sebagai alternatif untuk mempercepat upaya peningkatan produksi daging, baik untuk mengurangi impor daging maupun sebagai konsumsi masyarakat untuk peningkatan gizi. Salah satu alternatif yang dapat ditempuh adalah dengan jalan diversifiasi produk yaitu pemanfaatan produk-produk unggas, baik unggas yang sudah populer (ayam ras dan buras) maupun unggas lainnya (bebek dan entok). Ternak bebek sebagai salah satu sumber protein hewani memang patut dipertimbangkan.

Beternak bebek juga memiliki kelebihan jika dibandingkan dengan ternak unggas yang lainnya, dimana tubuh bebek lebih tahan terhadap penyakit sehingga pemeliharaannya mudah dan kurang mengandung resiko, serta daging bebek rasanya lebih gurih dibanding daging ayam. Selain itu juga, bebek memilikiefiiensi dalam mengubah pakan menjadi daging yang baik (Akhadiarto, 2002). 
Bebek merupakan salah satu jenis unggas yang paling banyak dipelihara dan dibudidayakan untuk dimanfaatkan daging, telur dan bulunya. Bebek adalah hewan yang masuk dalam spesies unggas. Bebek merupakan kerabat dekat dengan ayam, burung, dan juga angsa. Hewan unggas yang satu ini tergolong sebagai hewan yang suka hidup bergerombol. Bebek terkenal memiliki kualitas telur yang bagus serta daging yang gurih dan lezat. Telur dan daging bebek sudah banyak diolah menjadi beberapa produk seperti telur asin, lalapan, geprek, dan bebek goreng crispy.

Salah satu daerah di Lombok yang masyarakatnya menjadi peternak bebek adalah Desa Pengadang Praya Lombok Tengah. Kelompok peternak mendapatkan bantuan bebek dari pemerintah daerah guna meningkatkan perekonomian masyarakat. Kendala yang dihadapi adalah sebagian dari peternak belum memiliki pengetahuan dan keterampilan dalam mengolah daging bebek sehingga mereka menjual daging bebek segar ke pedagang lalapan atau pedagang makanan lain yang berbahan baku daging bebeb yang ada di Lombok Tengah hingga Mataram. Para peternak perlu diberikan pelatihan mengenai teknologi pengolahan daging bebek menjadi geprek, bebek penyet, dan bebek crispy.

Diversifikasi produk bebek selain bertujuan untuk meningkatkan nilai ekonomi bertujuan juga untuk meningkatkan nilai gizi, dan meningkatkan mutu daging bebek. Potensi pasar olahan bebek di NTB khususnya Pengadang Lombok Tengah cukup tinggi. Aneka olahan bebek sedang menjadi trend kuliner di masyarakat. Hal ini dapat dilihat dengan banyaknya stand penjual aneka olahan bebek. Apabila kualitas olahan bebek yang baik, maka dapat dijadikan usaha yang memberi keuntungan yang banyak. Oleh karena itu, diharapkan dengan adanya kegiatan pelatihan ini dapat memberi tambahan pengetahuan dan keterampilan dalam mengolah daging bebek menjadi aneka jenis olahan.

\section{METODE}

Kegiatan pengabdian ini dilakukan di Pengadang Lombok Tengah dengan melibatkan peternak bebek dan ibu-ibu rumah tangga yang terdapat di desa tersebut. Kegiatan ini dilakukan melalui pelatihan kepada masyarakat dengan metode ceramah, diskusi, dan praktik. Survey potensi dilakukan untuk mengetahui keberadaan dan perkembangan potensi bahan baku dan sumber daya manusia di Pengadang Lombok Tengah untuk pelaksanaan kegiatan ini. Penyuluhan dilakukan untuk menyampaikan berbagai informasi umum mengenai ayam seperti kandungan gizi, bebek, jenis produk turunan bebek, dan teknologi yang tepat dalam pembuatan produk turunan tersebut

Pada kegiatan ini akan dilakukan dua tahap evaluasi. Evaluasi tahap pertama dilakukan dengan menyebarkan kuisoner kepada peserta pelatihan. Kuisioner berisi pertanyaan tentang materi pelatihan. Penyebaran kuisioner ini bertujuan untuk mengetahui kesiapan peserta dalam menerima materi yang diberikan. Evaluasi tahap kedua dilakukan setelah penyampaian materi dan praktik. Evaluasi dilakukan dengan melihat kemampuan peserta dalam memahami materi dan kemampuan peserta dalam mempraktikkan pembuatan aneka olahan bebek.

\section{HASIL DAN PEMBAHASAN}

Kegiatan dengan tema "Transfer Teknologi Pengolahan Daging Bebek" di Desa Pengadang Praya Lombok Tengah merupakan salah satu upaya peningkatan pengetahuan dan keterampilan peternak bebek dan ibu-ibu rumah tangga di desa tersebut dalam mengolah daging bebek. Tujuan dari kegiatan ini adalah untuk meningkatkan pengetahuan dan keterampilan dalam mengolah bebek menjadi berbagai produk turunan seperti geprek, lalapan, dan crispy. Dengan adanya kegiatan ini diharapkan para peserta mendapat motivasi untuk mengolah daging bebek sehingga memiliki nilai jual yang lebih tinggi dan bisa merintis usaha baru produk olahan daging bebek. Kegiatan pelatihan 
telah dilaksanakan pada tanggal 1 Februari 2020 dan dihadiri oleh 20 orang Kegiatan diawali dengan acara pembukaan, penyampaian materi/penyuluhan, praktik pembuatan geprek, lalapan, dan crispy serta diskusi.

Materi penyuluhan berupa informasi umum mengenai bebek seperti kandungan gizi, umur simpan, pengolahan daging bebek yang biasa dilakukan masyarakat, jenis produk turunan daging bebek, dan teknologi yang tepat dalam pembuatan produk turunan tersebut.

Pada kegiatan ini diberikan pelatihan pembuatan geprek, lalapan dan crispy. Proses pembuatan ketiga produk tersebut hampir sama dengan geprek, lalapan dan crispy dari daging ayam. Beberapa hal yang perlu diperhatikan agar dapat menghasilkan produk berkualitas tinggi adalah kesegaran bahan baku, proses pengolahan yang tepat, sanitasi dan higiene. Beberapa hal yang perlu diperhatikan dalam mengolah daging bebek agar menghasilkan olahan yang tidak amis adalah daging berasal dari bebek yang muda, ujung ekor bebek dipotong, daging bebek dicuci dengan daun pepaya dan direbus dengan rempah-rempah, atau dipanggang dengan posisi menggantung.

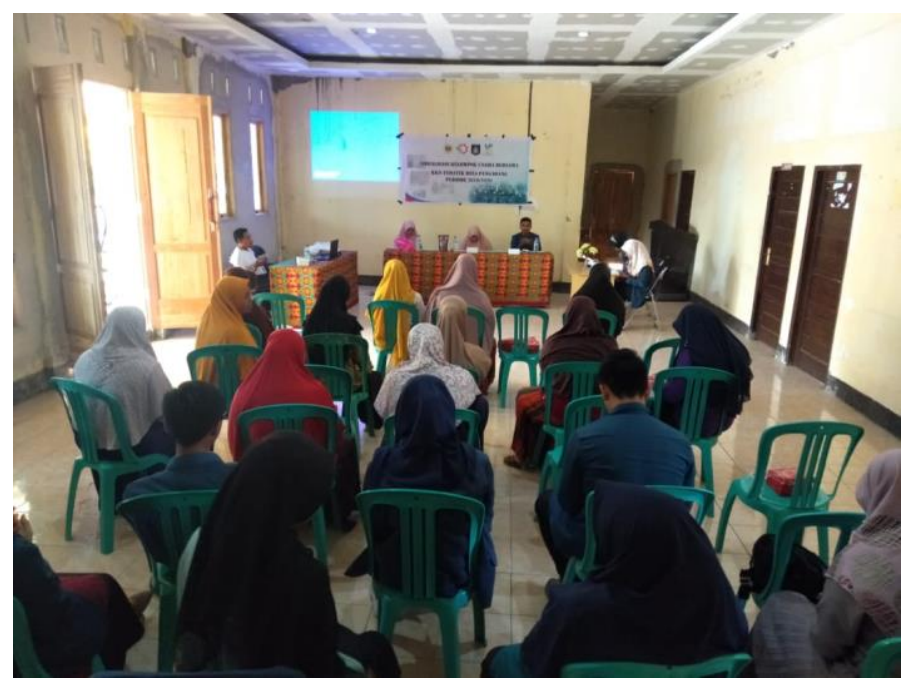

Gambar 1. Para Peserta Mendengarkan Penjelasan Tentang Teknologi Olahan Daging Bebek

Praktik pembuatan geprek diawali dengan memotong bebek menjadi beberapa bagian dan merebus daging bebek dengan bumbu-bumbu yang sudah disiapkan hingga bumbu tersebut meresap ke dalam daging, didinginkan, digoreng, kemudian digeprek dengan sambal yang sudah disiapkan. Adapun praktik pembuatan lalapan dan crispy daging bebek sama dengan pembuatan lalapan dan crispy dari daging ayam. 

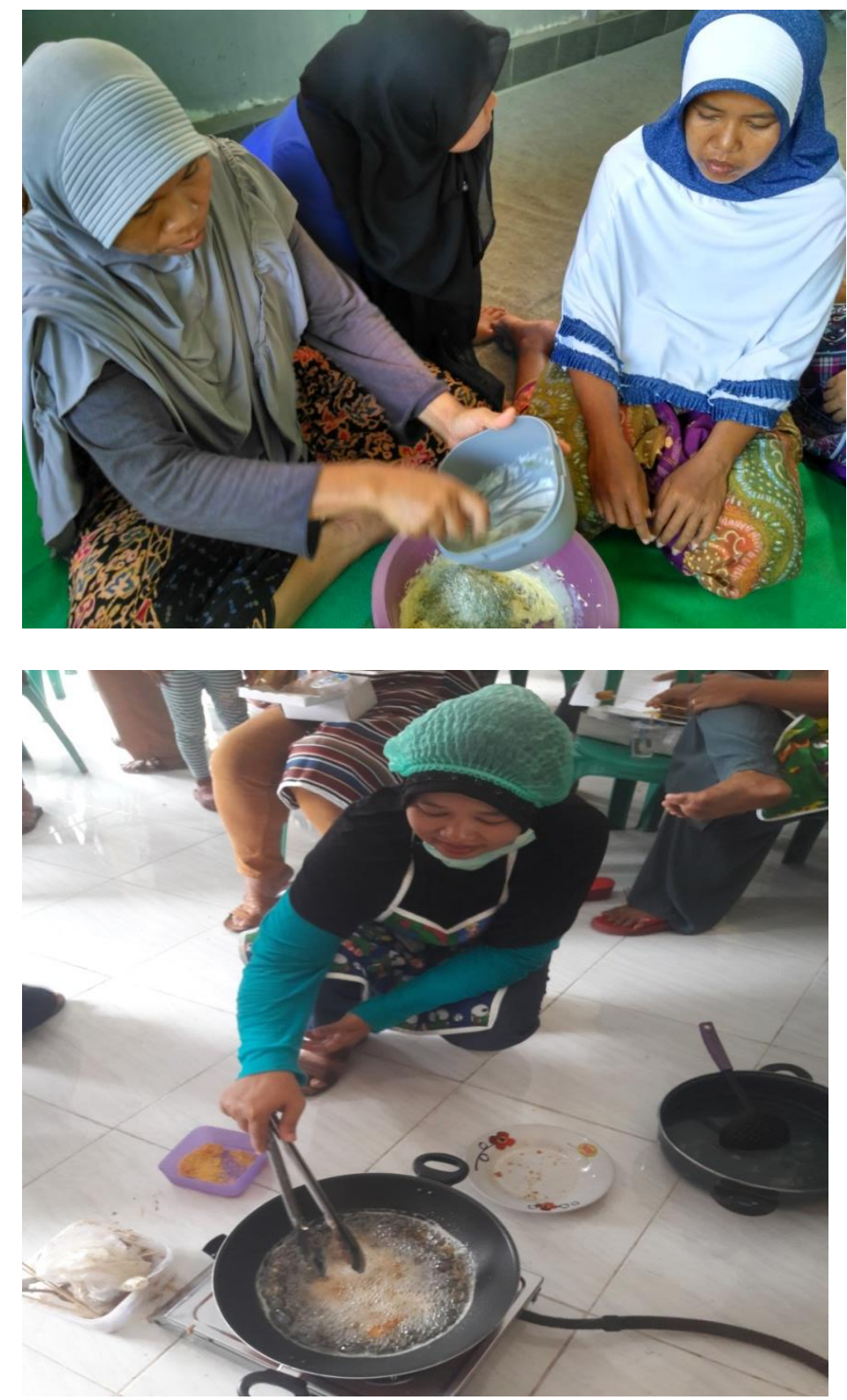

Gambar 2. Praktik Pembuatan Olahan Daging Bebek 


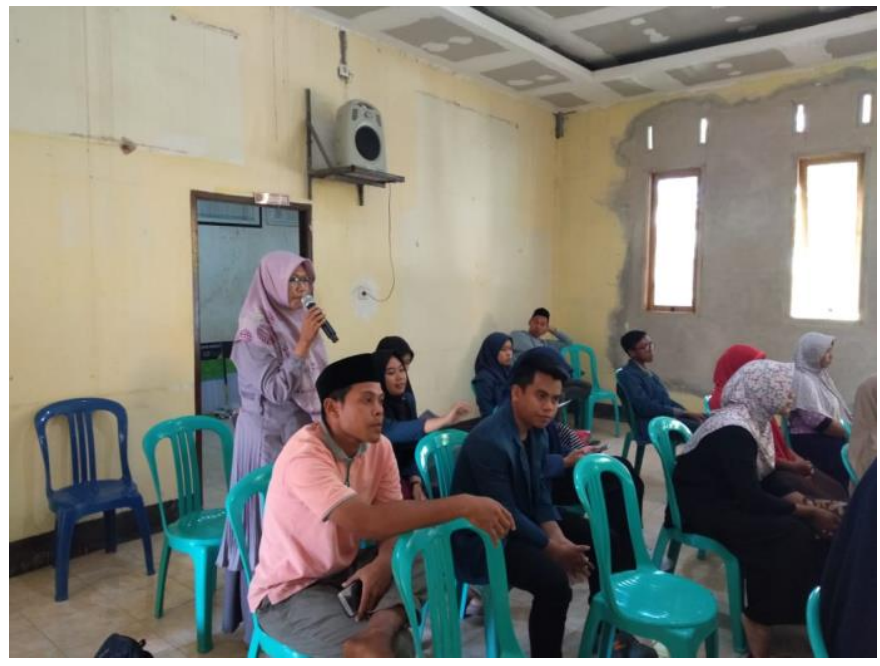

Gambar 3. Diskusi Setelah Praktik Pembuatan Olahan Daging Bebek

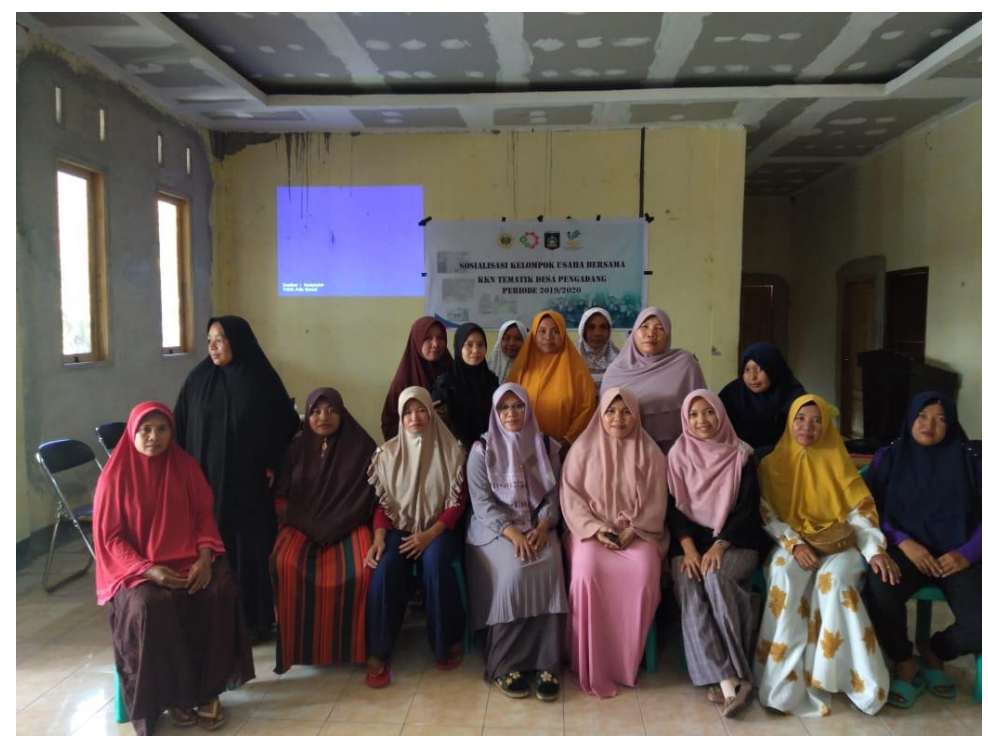

Gambar 4. Peserta Pelatihan Olahan Daging Bebek

Tahapan terakhir kegiatan ini adalah diskusi dan evaluasi. Berdasarkan pemantauan selama kegiatan berlansung diketahui para peserta pelatihan menguasai teknik pembuatan berbagai olahan daging bebek. Kegiatan ini secara keseluruhan berjalan dengan baik. Keberhasilan pelaksanaan kegiatan ini didukung oleh beberapa fakor seperti antusiasme dan komitmen peserta yang tinggi untuk mengembangkan daging bebek menjadi berbagai jenis olahan. Antusiasme adalah bagian besar dari motivasi peserta untuk hadir dalam kegiatan ini. Selain itu, para peserta merupakan kelompok yang bisa diajak bekerja sama dalam melaksanakan kegiatan pelatihan ini. Hal ini merupakan modal penting dalam mengembangkan usaha pengolahan daging bebek.

\section{SIMPULAN}

Kegiatan "Teknologi Pengolahan Daging Bebek" dilaksanakan di Desa Pengadang. Kegiatan ini melibatkan peternak bebek dan ibu-ibu rumah tangga yang terdapat di desa tersebut yang berjumlah 
20 orang. Kegiatan pengabdian diawali dengan survey potensi daerah, pengumpulan data, penyuluhan produk turunan dan teknik pengolahannya, serta praktik pembutan olahan daging bebek. Kegiatan berlansung dengan baik dimana peserta serius mengikuti pelatihan dan bisa mempraktikkan pembuatan olahan daging bebek. Pelatihan ini diharapkan mampu meningkatkan pengetahuan dan keterampilan peternak bebek dan ibu-ibu rumah tangga dan masyarakat secara umum. Pelatihan tersebut diharapkan mampu meningkatkan motivasi mereka untuk merintis usaha produk pangan berbasis daging bebek sehingga dapat meningkatkan perekonomian masyarakat.

\section{DAFTAR REFERENSI}

Akhadiarto. 2002. Kualitas fisik daging itik pada berbagai umur pemotongan. Pusat. Pengkajian dan Penerapan Teknologi Budidaya Pertanian. BPPT, Bogor.

Baiwat, Y.F., 2004. Pangan dan Gizi. Penebar Swadya: Jakarta

Soeparno. 1994. Ilmu dan Teknologi Daging Cetakan ke-2. Gadjah Mada University Press. Yogyakarta.

Susilorini, T.E, Muharlien dan M.E. Sawitri. 2008. Budidaya 22 Ternak Potensial. Penebar Swadaya. Jakarta.. 